\title{
The Study and Practice of Theory and Composition Among Women in Ghana
}

\author{
Joshua Alfred Amuah \\ University of Ghana, Legon-Accra, Ghana
}

\begin{abstract}
The performance and composition of traditional choral music were championed and dominated by women. Unfortunately, the involvement of women in the practice of art music, specifically theory and composition in Ghana has been observed to be absent or very minimal, the cause of which is problematic to identify. This paper examines why women have been passive in the performance and composition of this musical genre, and suggests avenues for improvement in the situation. Fifteen women across various musical genres: Traditional, Art and Popular were interviewed to ascertain this fact. The results will serve as an aid for an improvement of this unfortunate situation in Ghana.
\end{abstract}

Keywords: theory, composition, traditional, popular, art

\section{Introduction}

It has been observed that Music, unlike the visual arts, is not given prominence in the keeping of records from the ancient times. In this respect, the history of Western music does not really get rolling until the middle Ages - and one of the most dominant musical figures of that era is a woman, the German abbess St. Hildegard von Bingen (1098-1176 C.E.).

This paper provides three sections: The first section explains the expressions such as theory, composition, traditional, popular and art to readers for assimilation in the context of present study; Whilst the second section examines the extent of women's participation in Art Music (theory and composition); In the third section, the paper reports the responses from interviewees, draws conclusions and builds recommendations.

\section{Explanation of Keywords}

Terminology and concepts might sometimes lend to polysemy. Therefore, from the beginning of this paper, an exegesis of keywords on the topic will better offer an understanding of the precise perspective of the study. In this regard, five concepts the author use deserve definitions: theory, composition, traditional, popular and art.

\section{Theory}

According to Randel (1986):

Theory is the abstract, principles embodied in music and the sounds of which it consists. With respect to Western music, theory has traditionally encompassed the properties of single sound-pitch, duration, timbre, and those of collections of sounds: acoustics, tuning and temperaments, intervals, consonance and dissonance, scale, modes, melody, harmony, counterpoint, rhythm, meter, form, and analysis. He concludes that "today, the term also refers specifically to the teaching

Joshua Alfred Amuah, Ph.D., lecturer, Department of Music School of Performing Arts, University of Ghana. 
of the fundamentals or rudiments of music. (pp. 844-845)

\section{Composition}

The Encyclopedia Britannica (2010) defines composition as:

The act of conceiving a piece of music, the art of creating music, or the finished product. These meanings are interdependent and presume a tradition in which musical works exist as repeatable entities. In this sense, composition is necessarily distinct from improvisation. At its most fundamental level the act of composition involves the ordering of pitched sounds in musical time and space. (p. 294)

Theory and composition is being used in the context of the two definitions above. In a nut shell, conceiving and applying the properties of theory into an art of creating music constitute the reference point of this paper.

\section{Traditional Music}

Traditional music has been used here to indicate that there are other concurrent types of music in the same society. Nketia (1974), Agawu (1984), and Middleton (1990), argue that three distinct practices of music-making may be distinguished in most societies: the traditional, popular and art (or classical music, elite music).

Fiagbedzi (2010) states: The dictionary gives us a definition for tradition "an old habit of a group of people" and for "traditional" the definition "according to old habits". In the case of traditional music, this would mean that it is a music that belongs to a certain group of people and they have been practicing this music for a long time. By lack of any better term to define the music of homogenous groups in Ghana that is associated with old institutions, the author will use the term "traditional music" in the way Nketia (1963) uses it:

The musical scene in Africa today is a very complex one, for it reflects not only the diverse ethnic composition of the continent, but also the duality of old and new. Indigenous and foreign that characterizes modern Africa. Accordingly, one must distinguish between traditional music - music which utilizes the resources and modes of expression cultivated in the period before active colonization, and new modes of expression in the idioms of popular and the fine art music which are cultivated by Africa's population exposed to the impact of colonialism, the mass media, and western institutions. (p. 1)

At another instance Nketia (1978) posits:

In Ghana, traditional music is the music of indigenous institutions which developed in the pre-colonial period. It represents the artistic expression of Ghanaians in response to the needs and pressures of their own environment. Examples of this music are work songs such as those sung by the fishermen and craftsmen and farmers. They also include dirges, lullabies and the music that accompanies the celebration of such rites as circumcision, puberty and marriage. (p. 1)

\section{Popular Music}

The popular tradition was initially fashioned in contradistinction to the elitist tradition of art or classical music and the so-called "sublime, innocent” genre of traditional music (Omojola, 2006, p. 1). The term popular music reflected a class-oriented use that was concomitant with the stratified social structure of the Western world. It is a generic term for music throughout the age which appeals to popular tastes because of the means of dissemination (for example being aired on the radio). However, this has become a challenge because "all sorts of music, from folk to art, are subject to mass mediation” (Omojola, 2006, p. 1). In other words, it is a type of music that forms part of popular culture. The term "popular culture" here is defined in the traditional sense to mean the day-to-day culture of the people. According to Adjaye (2004), such popular culture in the traditional sense "finds expression in the way we live, the things we think about, the people around us, and their activities" (p. 3). And the major components of this popular culture, he continues, "are objects, persons and events, but it is through the use of symbols that popular culture is mostly constructed" (p. 3). 
Few scholars in the humanities have proposed varied definitions of Popular Music. For example, Birrer (1985) presents four definitions of popular music: the normative; the negative; the sociological; and the technologico-economic. In the Normative dimension, he claims that popular music is an inferior type of music. With the Negative he says that popular music is usually "folk" or "art". He also asserts that popular music is closely associated with a particular social group on the face of the Sociological definition, and finally he states it is the music which is disseminated by mass media and/or in a mass market on the side of the Technologico-economic.

Middleton (1990) on the other hand claims that all these definitions are interest-bound, and none therefore is satisfactory. He concludes that popular music must be realized in relation to the musical field. Barber (1987) argues that:

This is of course, a caricature of the prevalent view. Few would now accept the implication that so-called traditional society is represented by a static, closed, consensus village community, let alone the idea that the popular artist is a happy-go-lucky child-like innocent. (p. 10)

Thus, whilst traditional arts, of which music is a constituent, are recognized as an object of study in its own right, popular ones can only be established by reference to their distinction from the traditional forms. In effect while the traditional is realized as the point of beginning, the popular is ascertained by the extent to which it diverges from the traditional. Therefore definitions of these types are dependent on the situation of performance.

Other authors claim it is not possible to differentiate between traditional and popular music in some communities in Africa because the characteristics that have been assigned by other authors interweave the two types. This has been asserted by Waterman (2000):

To draw a sharp boundary between "traditional” and "popular” music in Yoruba society is impossible. The criteria most commonly invoked in attempts to formulate a cross-cultural definition of popular music-openness to change, syncretism, intertextuality, urban provenience, commodification—are characteristic even of those Yoruba musicians and audiences identify as deep Yoruba. (p. 214)

This quotation implies that in the Yoruba society there is no distinction between traditional and popular music. They share common characteristics. Therefore, to offer distinctive features to the two music genres depends on the context of performance.

Notwithstanding, Popular Music is created by professional, semi-professional and informally trained musicians to be enjoyed by the masses, often in an urban setting. It is the most popular of all types of music and the most commercially accepted and promoted. It is made up almost entirely of songs that cover a wide range of socio-cultural subjects, with instrumental accompaniments by groups of performers. The songs have melodies and lyrics or words that are easy to remember, however, many of these easily become popular, quickly then fade out just rapidly. In most cases, the music has not been written down or notated and thus its performance differs from performers to performers.

Popular Music is for dancing, singing and listening, and is mostly heard on phonograph records, on radio, and television. It is mostly performed for entertainment. The instruments used are mostly a combination of Electronic Guitars and Percussion, Woodwind, Brass, and keyboard instruments with occasionally, traditional instruments for special effects. The popular music includes such divers styles as the Jazz, Rock, Reggae, Calypso, Juju, Highlife, Congo, Samba, Soul, Afro-beat and Gospel. 


\section{Art Music}

According to Agawu (1984):

For lack of a better term, what he has called the "classical" tradition refers to the music of educated composers. Because their works are directed towards a nonparticipating, rather than a participating, audience, classical composers stand apart from their traditional counterparts. Furthermore, classical music belongs to a written tradition, not an orally transmitted one. Composers such as Akin Euba, Fela Sowande and Sam Akpabot of Nigeria, Ephraim Amu and Kwabena Nketia of Ghana belong to this tradition. (p. 38)

In general, art music is seen as separate from both popular and traditional music though there are elements that cross boundaries depending on the level of absorption of pre-compositional materials. These notwithstanding, the three classes cannot be offered distinctive definitions because they are limitless in concept. Barber (1987) therefore states:

Traditional, popular, and elite (art) must not be taken as empirical classes of products; they represent expressive fields with their own centers of gravity, characteristic tendencies, pulls of influence, and modes of orientation. They are concentrations of certain styles of expression at different locations in the social map, rather than hard-and-fast categories. Treated in their manner the distinctions are valuable, indeed crucial, if we are to understand what is happening in African culture today and what the practitioners of the arts themselves conceive themselves to be doing. (p. 19)

Barber thus indicates that definitions of the types cannot be decided in isolation as some authors indicate. The types rather are related to each other, and the performance situation determines the definition given to each of them.

\section{Women's Involvement in Traditional Music Composition and Performance}

The involvement of women in traditional activities such as music and dance has been posited by Fiagbedzi (2010) as: In African societies, cultural norms have given women the opportunity to involve themselves in traditional music performances. He concludes that the African women's involvement in music performances dates back to centuries (p. 17). Collins (2005) makes references to Frisbie (1971, p. 274) and Turnbull (1962, p. 206) that “the hunter-gather societies of Kung 'Bushmen' of South African and the Mbuti pygmies of Zaire were completely egalitarian in their music making". Roberts (1974) claims "there is a wide spread African tendency to regard certain sorts of music and musical instruments as being of women" (pp. 50-51).

The performance and composition of women in the forefront in traditional choral music have been substantiated by Nketia (1963), Dor (2005), Agawu (1995), Ampene (1999), and Turkson (1975). It is rather unfortunate that women who took the center stage in traditional music performances and composition are currently not found in the field of Art music, specifically, in theory and composition in Ghana. Amuah (2012) posits that:

The efforts of women in performance of traditional choral styles are highly appreciated. This has attracted research interest including Ampene (1999) on EfuaAbasa (a prolific Akan Nnwonkor ${ }^{1}$ /Adowa composer). Moreover, a few African women composers have reached international heights in the class of popular music. This has not been the situation with art choral music composition. (p. 203)

According to Dor (2005):

${ }^{1}$ A female song tradition confined to adult women in Ghana. 
The use of the term "art" to describe choral music implies the existence of another type of choral music. Ghanaian ethnic groups have traditional choral styles quite distinct from the art choral idiom which exists in oral traditions, often with precise vocabulary that distinguishes them as song sub-genres. For example, Ewedome (Northern Ghanaian Ewe) women sing Avihawo part songs of lament, accompanying themselves with rattles. Similarly, the early female Christian converts in the Fanteland of coastal Ghana developed and performed Ebibindwom, a traditional choral genre in the Methodist Church. (p. 447)

Before the arrival of the missionaries in Ho, all societies in the Volta Region practiced traditional religion; therefore all women in the region performed avihawo. Agawu explains that Avihawo is a traditional dirge which formed the backbone of musical performance at funerals in the pre-Christian era, and was sung by adult women.

According to Ampene (1999):

Nnwonkor is a female song tradition confined to adult women in Ghana who in the past sang to entertain themselves in the night when the moon shone bright in the sky. Today, the Nmwonkor tradition has been brought out into broad daylight to celebrate festive occasions publicly in both secular and sacred contexts. (p. 1)

Ampene (2005) establishes that in Ghana today:

The adowa ensemble, generally regarded by the Akans as the classic funeral dance, takes center stage in providing songs. Right away, one time-traveller would observe that adowa ensembles featured both sexes, with men playing the atumpan $^{2}$, the apentema drummer drums in addition to the adawura ${ }^{3}$ while the women constituted the chorus. (p. 18)

Turkson on another instance declares that the lyric as a musical type owes its development during the office of Rev. Thomas B. Freeman, by non-literate members of the church in Cape Coast in 1838. When Freeman realized that the non-literate members of the church did not participate in singing of the English Hymns he encouraged older women to sing biblical text to traditional tunes.

Haydon (1985) and Marks (1985) also proclaim that people of the Volta Region of Ghana perform a musical type called gbolowhich is reserved for women. The Ga people of Ghana also have a recreational music type for only females known as adaawe. The people of Akuapem Mamfe also have a musical type for females called $a b a \jmath^{4}$. In Northern Ghana, there is a twirling dance for Dagomba men called takai and one for the women call tora.

Essandoh (1998) making an input in the argument that women championed and dominated in the study and practice of traditional music states: "Even though there is no tradition of female profession musicianship in Ghana such as the djelemouso or griot of Mali and Senegambia, traditional communities all over Ghana provided opportunities for women in music making” (p. 102). Nketia (1963) substantiates this: Music associated with the rites of puberty among all tribes involved women (pp. 52-56). Singing of funeral dirges has also been an all-female affair (Nketia, 1955, p. 16). Recreational or popular bands that have been organized as exclusive women bands include the Fante Adenkum (Anning, 1965, p. 64), and Adzewa and the Asante Nnwonkors. There also were the mixed groups such as Asante Adowa, Fante Ahyewa and Apatampa, Ewe Agbadza and $B \supset b\lrcorner b \supset^{5}$ (Nketia, 1963, p. 71; Mensah, 1971, p. 22; Opoku, 1970, pp. 35-36). Essandoh (1998) concludes that in all of these ensembles, women sing, dance, and play their roles were all socially approved (p. 104). Sasu (2006) validating these assertions advance that:

\footnotetext{
${ }^{2}$ A pair of bottled-shaped drums, played by the lead drummer.

${ }^{3}$ Boat-shaped, hand-held iron idiophone.

${ }^{4}$ Female musical type found in Akuapem Mamfe.

${ }^{5}$ Female musical type of the people in the Volta Region in Ghana.
} 
Even in the musical types/forms which both men and women perform, women are usually the singers and dancers. Also, in some dance ensembles like Nnwonkors of the Ashantis and Adzewa and Apatampa of the Fantis which are traditionally performed by women, the musical instruments are usually played by men. (p. 7)

\section{Women in the Performance and Composition of Popular Music}

In the Popular musical genre it is evident that lot of women have excelled as indicated earlier by Amuah (2012) in his submission. December edition of People and Places (P\&P, 1986), Arts and Entertainment page extracts this statement: "The gospel music industry has yet another fresh artiste added to its long list of new entrants. Increasing the percentage of female gospel artiste to about 80\% comes Mrs. Gifty Agyemang Prempeh...” (p. 4). In affirmation of this statement Essandoh (1998) informs that:

Regardless of the exactitude of the figure $80 \%$, of the gospel-highlife recording scene of the late 1990s is undoubtedly dominated by women as soloists, duets, and trios. To put it differently, the most visible faces and the most audible voices in the contemporary gospel-highlife arena are women. Naana Gyamfi, Juliana Acheampong, Diana Hopson, Helena Rabbles, Mary Ghansah-Newman, Stella Dugan, Naana Frimpong, Army Newman, Georgina Juliet Antwi, Naana and Dan, Tagoe Sisters, Suzy and Matt, Gertie and Friends, and Daughters of Glorious Jesus are all household names from the gospel-highlife establishment. (p. 98)

In the church, especially in the Methodist Churches, women played pivotal roles. Essandoh (1998) once again declares that Christianity, specifically Methodism, provided a grand avenue for the exposition of female musical talent by permitting the development of the Ebibindwom which has mostly been led by elderly female members of the congregation (Turkson, 1972, p. 139). He also indicated that the Singing Bands ${ }^{6}$ were constituted almost entirely by women. The Singing Bands sung anthems of a different kind, native anthems, one might call them, were in the vernacular (p. 99).

\section{Women in Art Music (Theory and Composition)}

Amuah (2012) suggests four generations of choral music composition. The prominent composers among each generation are as follows: The first generation consists of Ephraim Amu, Isaac Daniel Riverson, and their contemporaries. The second generation comprises J. H. Kwabena Nketia, Atta Annan Mensah, AldophusAto Turkson and their contemporaries, while the third generation includes Kenn Kafui, George W. K. Dor and contemporaries. The fourth generation has Samuel Asare Bediako, Newlove Annan and their contemporaries (Amuah, 2012, p. 3).

From the full list of the generational map, not a single woman has been listed as a composer in any of the generations. In the field of Art music in general, few women have made impact but have made no contribution to the field of composition. Okwan (2013) informs that "we have some women who have also ventured into music education and are out there performing marvelously” (p. 56). She concludes by documenting very brief profiles on some of them.

(1) Dinah Reindolf: She is the first female Director and successor to Philip Gbeho7. She directes the orchestra from 1972 to 1984 (a period of twelve years). She has a strong attachment to Ghanaian choral works, in part due to the training she has in choral conducting at the Royal Academy of Music in the United Kingdom (Dortey \& Arhine, 2010).

(2) Grace Adjei: She is in charge of voice as an instrument and helps to shape the tone quality of the

\footnotetext{
${ }^{6}$ An indigenous version of the church choirs which led the congregation in hymns, and also rendered the anthems that were extracted from the western classical repertoire.

${ }^{7}$ He was the second director of the National Symphony Orchestra. He took over after Robert Kwami’s death.
} 
instrument of many students trained in the National Academy of Music which is now the Music Department of the University of Education, Winneba.

(3) Mary Dzansi Mc Palm: She is a beacon of hope for many females in the area of music. As a Professor of music, she continues to nurture many students at the University of Education, Winneba. She is one of the few who rub shoulders with males in the academic enterprise; she is currently the Dean of the School of Creative Arts.

(4) Augusta Addo: She is an up and doing music educator currently lecturing at the University of Education, Winneba. A prolific alto singer who keeps audience spell bound with her solo performance. She is indeed an inspiration to many students in the field of music.

(5) Theodora Entsua-Mensah: She is one of the few females who demonstrate great competence in the playing of the keyboard at the University and in public performances. She is academically excellent and versatile in the various aspects of music. She has melodious voice. She is still making it great in real life situation at the Methodist University College as lecturer.

(6) Comfort Akosah: She is another prolific singer who has a captivating soprano voice. She is currently the Vice Principal of the Saint Louis College of Education, Kumasi and has for several years served as the Director of Music for the Association of Methodist Church Choirs in Ghana8.

(7) Salome Odeng: She is a very quiet and unassuming at post as music educator and a delight to watch at the soprano saxophone. She is a Music and Dance tutor at Abetifi Presbyterian College of Education, Kwawu.

(8) Gladys Offei: She is a daughter of a musician who shows immense proficiency at the keyboard. Inspired early to be in music by her father, she has never looked back. She is now the Music and Dance tutor at the Presbyterian Women's College of Education, Agogo, Asante-Akyem. Gladys also handles a lot of the choirs in the Presbyterian Church and has been adjudicating in several music competitions.

(9) Elizabeth Sasu: She is very good at traditional music and has a great flare for singing. She also continues to encourage many as a music educator and a positive role model. Currently, she is the headmistress of St Francis Senior High Technical School Akim Oda.

(10) Margaret Ferguson: She has been one of the few females who have shown great competence in singing. Her trilling voice takes her to several places. She is academically sound in the various dimensions of music. She currently resides in United Kingdom and performs solo works of great composers.

After a careful examination of the brief profiles of a few women in the field of Art music, there is the evident that none is into theory and composition sector. Sasu (2006) informs that:

In art music, few women have come up to national recognition. Although there are now some women composers of choral music, very little is known about them. Most of the choral music groups are directed by men who do not feel comfortable to teach and conduct music composed by women. (p. 7)

The author argues that none of these has any choral works. Sasu would have mentioned titles of their works. It could be true that they made an attempt at choral composition but the author seemingly do not agree that any of them is a habitual choral music composer like men do. The attempt they have made at composition might be at the time they were completing either their Diploma programme or Bachelor of Education programme, which obliged them to compose as a requirement in partial fulfillment of the course of study.

${ }^{8}$ A Union of all Methodist Church choirs in Ghana. 


\section{Responses From Interviewees}

In all, fifteen musicians were sampled for interviews, five from each musical genre; traditional, art and popular. Interviews conducted gave the following responses.

\section{Traditional Musicians}

Women in the performance and composition of traditional music indicated that they have learned informally to sing from their mothers from an early stage in their lives, and since they did not experience any formal education, there was no way possible for them to compose by "pen and paper". This is confirmed by Mokwunyei (1998) as:

Children get involved in various forms of musical experiences at an early stage in Ghana as in other parts of Africa. In fact, music making and learning begin right from birth, where women as mothers, are the main agents and facilitators. (p. 434)

\section{Popular Musicians}

Women in popular music gave similar responses. They indicated that they had little formal music education at the basic and secondary schools which did not equip them with the necessary skills and competence to put music on paper. They therefore delighted to learn by rote, so when the opportunity came for their involvement in singing and performing on other instruments with church bands, they made that a golden opportunity to end their compositional and performance skills there, since they felt they have already gained popularity in the church. (Makore, 2004, \& Collins, 1991) confirm as "most of the women in the popular music like their counterparts in Zimbabwe are enjoying some popularity because their works are based on the Christian faith and the 'Goodness of God'” (2003, p. 8).

\section{Art Musicians}

The author had the opportunity to interview five from among the ten women art musicians whose brief profiles have been provided in the preceding paragraphs. The responses which were varied, and yet boil down to the same point indicate that none of them practices theory and the art of music composition. Only three out of the eight identified women in the academia are performers, either as voice soloist or pianists. Three out of the eight teach in the universities, three teach in the Colleges of Education and two are heads of institutions in the Senior High Schools.

Firstly, it has been a worry, why a single female music scholar cannot be identified among the male theorist/composer counterparts. The responses from the interviews conducted to ascertain the fact indicate that after their diploma in music education at Winneba, they are posted to the basic schools to teach. Unfortunately, music has been clustered with a number of subjects and tagged Cultural studies, Music and Dance and Creative Arts. The course content is such that you cannot teach theory and composition. There is no way they could practice the theory and compositional techniques acquired during their formal school days. This therefore discourages them from involving themselves in the art of composing. The author argues that women could still compose irrespective of the course content of what they teach. This argument stems from the fact that they have already been equipped with the rudiments for composition and they do not need to learn any compositional techniques from what they teach at the basic level. More so, their male counterparts face the same challenge in their schools though. 
Secondly, when one is posted to the Colleges of Education the content of the curriculum is tilted towards teaching of African Music and Dance and the focus is just to help students pass their examinations and to go out and impart what the teacher has taught them. Becoming a theorist or a composer cannot be achieved at the level. At the Senior High School where one can practice alongside teaching, the work load is very huge and does not permit that. The author still argues that women could still have composed in the vein of African Music, so the excuse that they teach African Music in the Colleges of Education does not "hold water".

At another instance, respondents indicated that some people are born teachers, others are born theorists and composers. So they feel women are born to teach so that they could bring up their children in the best way and not to seriously learn about theories of music and to compose which will always take their time and deprive them from taking good care of their children.

Other respondents also said they learn to play keyboard and learn to sing at an early age from their parents, so they grow up with those skills. All along they seem to be polishing what they have been taught at home and that is why they are stuck with performances.

The last respondent indicated that before one calls him/her self a composer or a theorist, he/she must be skillful and naturally talented in the art. The person must be brilliant and must have adequate time to devote to the art. Obviously, women like and love to perform for admiration. They do not have the time to learn conventions towards writing compositions, and that is why they have restricted their musical activities to teaching and performing. The respondents finally indicated they are naturally not comfortable with music theory and composition because it is a difficult area.

\section{Conclusions}

The practice of music with regard to performance and composition has been patronized by women from the traditional epoch. A lot of women have also shown interest in the popular musical genre. Though few women have excelled in the field of art music, they are confined to performing, either on the keyboard or singing. The investigation conducted has shown that no single woman can be seen with serious participation in Music Theory and Composition, just as Mathematics, Physics etc. are areas which scare most people, especially women.

It has been observed from the responses offered by the women interviewees that, women are palpably teachers and performers. The time to care for their children does not suffice committing part of it into learning and practicing theory and composition. The practice of theory and composition is rather difficult and therefore makes it irritating for them to engage themselves in.

\section{Recommendation}

It is recommended that women should be nurtured through the practice of theory and composition from an early age since those who find themselves in performance declare that they have loved to perform because they inherited performance from their parents at an early age. In the educational set up, teaching of music and for that matter theory and composition must be done at an early stage. Amuah (2012) confirms this as he says:

The making of a brilliant composer therefore begins at an early age. An advancement and experience therefore is sought in formal music institutions. It is therefore anticipated that a composer will be exposed to his traditional music at an early age. (p. 203)

Women in popular music who had informal music education and have experienced zero formal music education should be tutored to be able to compose simple melodies and its accompanying harmonization. The 
curriculum of the Ghana Education Service (GES) should be enriched in all levels; Junior High, Senior High and the Colleges of Education to incorporate theory and composition so that musical behaviour of products from these institutions will depict having gone through a rigorous course of study in all inclusive music learning.

This will not only produce better music personnel but also help teachers to learn theory and the art of composition which will put women at par with men when it comes to Music Theory and Composition.

\section{References}

Adjaye, J. K. (2004). Boundaries of self-other in Ghanaian popular culture. Westport, C.T.: Praeger Publishers.

Agawu, K. (1984). The impact of language on musical composition in Ghana: An introduction to the musical style of Ephraim Amu. Ethnomusicology, 28(1), 37-73.

Agawu, K. (1995). African rhythm: A Northern Ewe perspective. Cambridge: Cambridge University Press.

Ampene, K. (1999). The creative processes in Niwonkors A female song tradition of the Akan of Ghana. (Doctoral dissertation, University of Pittsburgh, PA, USA).

Ampene, K. (2005). A female song tradition of the Akan of Ghana. The creative processes in Nnwonkors. Pittsburgh: USA. Ashgate Publishing Limited.

Amuah, J. A. (2012). The use of traditional elements in contemporary Ghanaian choral music: Perspectives from selected works of Geroge Worlasi Kwasi Dor, Nicodemus Kofi Badu and New love Annan. (Ph.D. Thesis, University of Ghana, Legon).

Anning, J. L. (1965). Melodic analysis of the Adenkum. In Papers in African Studies (Vol. 3). Accra: Ghana Publishing Corporation.

Barber, K. (1987). Popular arts in Africa. African Studies Review, 30, 1-78.

Birrer, F. A. J. (1985). Definitions and research orientation: Do we need a definition of popular music?. In D. Horn (Ed.), Popular music perspectives. Sweden: University of Gothenburg.

Chernoff, J. M. (1985). The drums of Dagbon in repercussions: A celebration of African-American music. In G. Haydon \& D. Marks, (Eds.). London: Century Company.

Collins, J. (1991). “Classic” highlife tunes: Scores of almost one hundred dance band and guitar band highlife songs. Copenhagen: Fleming Harrev.

Dor, G. W. K. (2005).Uses of indigenous music genres in Ghanaian choral art music: Perspectives from the works of Amu, Blege, and Dor. Journal of Ethnomusicology, 49 (3).

Dortey, M., \& Arhine, A. (2010). The performance arts and the post-colonial Ghanaian experience: Ghana National Symphony Orchestra in perspective. African Studies Research Review, 26 (1).

Encyclopedia Britannica. (2010). New York: Encyclopedia Britannica, Inc.

Essandoh, I. K. (1998). Gospel Highlife: The status and impact of a Ghanaian Popular Music genre. (Unpublished M.Phil Thesis, University of Ghana, Legon).

Fiagbedzi, E. K. (2010). Women, music and culture: A study of Naaamanua, a neo-traditional Ghanaian musician. (Unpublished M. Phil Thesis, University of Ghana, Legon).

Frisbie, C. (1971). The Anthropology and ethnological implications of a comparative analysis of Bushmen and Pygmy music. Ethnology, 10 (3).

Makore, S. (2004). Women in music: Some notes on Zimbabwe. In S. Magnus (Ed.), Sounds of change: Social and political feature of music in Africa (pp. 47-56). Stockholm: Sida Studies.

Mensah, A. A. (1971). Folk songs for schools. Accra: Ghana Publishing Corporation.

Middleton, R. (1990). Studying popular music. Buckingham: Open University Press.

Mokwunyei, J. N. (1998). The role of women in African music. In C. VanNiekerk (Ed.), Proceedings of the 23rd ISME World Conference (pp. 434-442). PreForia: UNISA.

Nketia, J. H. K. (1955). Funeral Dirges of the Akan People. London: James Townsend and Sons Ltd.

Nketia, J. H. K. (1963). African music in Ghana. Chicago: Northwestern University Press.

Nketia, J. H. K. (1974). The music of Africa. New York: W.W. Norton and co., Inc.

Nketia, J. H. K. (1978). The typology of contemporary Ghanaian choral music. Accra: Arts Council of Ghana.

Okwan, F. (2013). Gender biases against women in the development of popular music in Ghana. (Unpublished M.Phil Thesis, University of Education, Winneba). 
Omojola, B. (2006). Popular music in Western Nigeria-Theme, style and patronage system. Ibadan: Gold Press Limited. Opoku, A. A. (1970). Festivals of Ghana. Accra: Ghana Publishing Corporation.

Prempeh, G. (1986). Arts and entertainment for December 12-18. People and Places (P\&P), p. 4.

Randel, M. (Ed.). (1986). The new Harvard dictionary of music. Cambridge, M.A.: Belknap Press of Harvard University.

Roberts, J. S. (1974). Black music of two worlds. William New York: Marrow and Company.

Sasu, E. (2006). Gender in musical arts practice and education in Ghana (Unpublished M.Phil Thesis, University of Education, Winneba).

Turkson, A. A. (1972). Effutu Asafo music: A study of a traditional music of Ghana with reference to the role of tonal language in choral music involving structural and harmonic analysis (Doctoral Dissertation, Northwestern University).

Turkson, A. A. (1975). Evolution of Fante sacred lyric. Research Review.

Turnbull, C.M. (1962). The forest people. New York: Touch stone books, Simon and Schuster.

Waterman, C. A. (2000). Yoruba popular music. In R. Stone (Ed.), The Garland encyclopedia of African music (2nd ed.). Bloomington: Indiana University. 